\title{
HUBUNGAN KETUBAN PECAH SEBELUM WAKTUNYA (KPSW) DAN SECTIO CAESAREA DENGAN KEJADIAN ASFIKSIA PADA BAYI BARU LAHIR.
}

\author{
Juliana Widyastuti Wahyuningsih \\ Akademi Kebidanan Budi Mulia Palembang
}

\section{Informasi Artikel :}

Diterima : $\quad$ Maret 2019

Disetujui : Juni 2019

"Korespondensi Penulis :

Yuliana_widyastuti@ymail.com

\section{A B S T R A K}

Menurut WHO setiap tahunnya kira-kira 3\% (3,6juta) dari 120 juta bayi baru lahir mengalami asfiksia. Menurut SDKI tahun 2012 angka kematian bayi sebesar 34 kematian/1000 kelahiran hidup. AKB di Sumatera Selatan tahun adalah 44,59 per 1000 kelahiran hidup. Sedangkan AKB di kota Palembang 2016 sebesar 44 per kelahiran hidup. Tujuan penelitian ini adalah untuk mengetahui faktor-faktor apa saja yang berhubungan dengan kejadian asfiksia pada bayi baru lahir di Rumah Sakit PT Graha Pusri Medika Palembang. Penelitian ini menggunakan metode survey analitik dengan pendekatan Cross Sectional. Populasi dalam penelitian ini adalah semua ibu yang bersalin di Rumah Sakit PT Graha Pusri Medika Palembang, yang berjumlah 1014 responden. Penelitian ini dilakukan pada tahun 2018. Sampel dalam penelitian ini adalah sebagian ibu yang bersalin di Rumah Sakit PT Graha Pusri Medika Palembang berjumlah 287 responden. Sampel penelitian diambil secara random sampling dengan teknik Simple random sampling. Analisa data menggunakan uji statistik Chi - Square. Hasil penelitian menunjukkan bahwa ada hubungan yang bermakna antara KPSW dengan kejadian asfiksia dengan $P$ value $(0,006)$, ada hubungan yang bermakna antara persalinan SC dengan kejadian asfiksia dengan $P$ value (0.009). Saran bagi rumah sakit dapat dijadikan masukan dalam mengupayakan pengembangan tatalaksana asuhan kebidanan dalam meningkatkan mutu pelayanan kesehatan terutama pada kasus-kasus yang berhubungan dengan kejadian asfiksia.

\section{Kata Kunci : KejadianAsfiksia}

\section{ABSTRACT}

According to WHO every year approximately 3\% (3.6 million) of the 120 million newborns increase asphyxia. According to the IDHS in 2012 the infant mortality rate was 34 deaths / 1000 live births. The IMR in South Sumatra in the year is 44.59 per 1000 live births. Where as AKB in Palembang city in 2016 is 44 per live birth. The purpose of this study was to study what factors are associated with the incidence of asphyxia in newborns at PT Graha Pusri Medika Palembang Hospital. This study uses an analytical survey method using Cross Sectional. The population in this study were all mothers who gave birth at PT Graha Pusri Medika Palembang Hospital, which examined 1014 respondents. This research was conducted in 2018. The sample in this study was that some mothers who gave birth at PT Graha Pusri Medika Palembang Hospital added 287 respondents. The research sample was taken by random sampling with Simple random sampling technique. Data analysis using Chi-Square statistical test. The results showed that there was a relationship between Premature rupture of membranes and the incidence of asphyxia with a $P$ value (0.006), there was a relationship involving between SC labor and 
the incidence of asphyxia with a P value (0.009). Suggestions for hospitals can be used to seek the development of midwifery care in improving the quality of health services related to cases related to asphyxia.

\section{PENDAHULUAN}

Asfiksia neonatorum adalah keadaan dimana bayi baru lahir tidak dapat bernafas secara spontan dan teratur segera setelah lahir. Keadaan ini biasanya disertai dengan keadaan hipoksia dan hiperkapnu serta sering berakhir dengan asidosis. Asfiksia akan bertambah buruk apabila penanganan bayi tidak dilakukan secara sempurna, sehingga tindakan perawatan dilaksanakan untuk mempertahankan kelangsungan hidup dan mengatasi gejala lanjut yang mungkin timbul (Arief, 2009).

Menurut World Health Organization (WHO) setiap tahunnya kira-kira 3\% (3,6 juta) dari 120 juta bayi baru lahir mengalami asfiksia, hampir 1 juta bayi ini meninggal. Di Indonesia, dari seluruh kematian bayi, sebanyak 57\% meninggal. Penyebab kematian bayi baru lahir di Indonesia adalah bayi berat lahir rendah (BBLR) (29\%), asfiksia (27\%), trauma lahir, tetanus neonatorum, infeksi lainnya dan kelainan kongenital (Wiknjosastro, 2008).

Menurut data Survei Demografi dan Kesehatan Indonesia (SDKI) tahun 2012 angka kematian bayi sebesar 34 kematian/1000 kelahiran hidup. Angka kematian bayi ini sebanyak $47 \%$ meninggal pada masa neonatal, setiap lima menit terdapat satu neonatus yang meninggal. Adapun penyebab kematian bayi baru lahir di Indonesia, salah satunya asfiksia yaitu sebesar $27 \%$ yang merupakan penyebab ke-2 kematian bayi baru lahir setelah Bayi Berat Lahir Rendah (BBLR) (Depkes RI, 2013).

Faktor resiko terjadinya asfiksia yaitu usia kehamilan/masa gestasi sangat berpengaruh pada bayi yang akan dilahirkan, faktor bayi prematur sebelum 37 minggu kehamilan dan faktor ibu yaitu kehamilan post term atau kehamilan melebihi 42 minggu (DepKes RI, 2009).

Asfiksia berarti hipoksia yang progresif, penimbunan $\mathrm{CO}_{2}$ dan asidosis. Bila proses ini berlangsung terlalu lama dapat mengakibatkan kerusakan otak atau kematian. Asfiksia juga dapat mempengaruhi fungsi organ vital lainnya (Prawirohardjo, 2009).

Angka Kematian Bayi di kota Palembang 2014 adalah 26,68 untuk laki-laki dan untuk perempuan 20,02 per 1000 kelahiran hidup. Pada tahun 2016 sebesar 44 per 1000 kelahiran hidup atau 100 kematian bayi dari 28.166 kelahiran hidup. Dari 100 kematian bayi sebanyak 35 janin lahir. Penyebab kematian bayi pada tahun 2016 adalah kematian perinatal (42\%), BBLR (27\%), Asfiksia (17\%), Kelainan kongenital (18\%), serta infeksi (2\%) (Profil dinkes kota palembang, 2018).

Ketuban Pecah Sebelum Waktunya (KPSW) merupakan kondisi dimana kantung ketuban pecah sebelum waktu persalinan dimulai. Ketuban Pecah Sebelum Waktunya (KPSW) merupakan salah satu penyebab terjadinya asfiksia neonatorum dan infeksi yang dapat meningkatkan mortalitas dan morbiditas perinatal. Nilai Apgar adalah cara untuk menilai kondisi postnatal yang mencerminkan fungsifungsi vital pada neonatus (Tjin Willy, 2019).

Persalinan sectio sesarea dilakukan pada faktor kehamilan dengan risiko tinggi sehingga persalinan tersebut mengakibatkan gangguan pada janin atau bayi baru lahir, oleh sebab itu secsio sesarea tidak dilakukan kecuali dalam keadaan terpaksa. Risiko persalinan sectio sesarea terhadap bayi baru lahir yaitu kematian bayi, risiko gangguan pernafasan bayi, risiko trauma bayi, dan risiko gangguan otak. Risiko yang dialami bayi baru lahir terkait secsio sesarea adalah 3,5 kali lebih besar daripada persalinan normal (Febrimulya, 2009).

Berdasarkan data yang didapat dari Rumah Sakit PT Graha Pusri Medika Palembang, angka kejadian asfiksia pada bayi baru lahir pada tahun 2015 sebanyak 88 kasus dari 730 kelahiran, pada tahun 2016 sebanyak 102 kasus dari 1203 kelahiran, pada tahun 2017 sebanyak 123 kasus dari 1245 kelahiran dan pada tahun 2018 sebanyak 146 dari 1014 kelahiran.

Maka berdasarkan latar belakang di atas, Penulis tertarik melakukan penelitian dengan judul" Hubungan Ketuban Pecah Sebelum Waktunya (KPSW) dan Sectio Caesarea dengan Kejadian Asfiksia Pada Bayi Baru Lahir.

\section{METODE PENELITIAN}

Jenis penelitian ini menggunakan metode survey analitik dengan pendekatan "cross Sectional" yaitu suatu penelitian yang semua variabelnya dikumpulkan sekaligus dalam waktu yang bersamaan. Penelitian dilakukan di Rumah Sakit PT Graha Pusri Medika Palembang Penelitian dilakukan pada bulan Maret tahun 
2019. Populasi dalam penelitian ini adalah semua ibu yang bersalin di Rumah Sakit PT Graha Pusri Medika Palembang. Pada penelitian ini besar sampel ditentukan dengan cara random sampling. Variabel Independen dalam penelitian ini adalah KPSW dan persalinan sectio caesarea sedangkan variabel dependennya adalah Asfiksia pada BBL.

Metode pengumpulan data dengan menggunakan ceklist, data-data sampel diperoleh dari medical record pasien.

Uji statistik dalam penelitian ini menggunakan Chi-Square dilakukan melalui proses komputerisasi dengan tingkat kemaknaan $(\alpha)=0,05$.

\section{HASIL PENELITIAN}

Analisa ini dilakukan terhadap 287 responden untuk mengetahui distribusi frekuensi dan persentase dari variabel independen (Ketuban Pecah Sebelum Waktunya (KPSW) dan Persalinan Secsio Sesarea) dan variabel dependen (asfiksia neonatorum). Data disjaikan dalam bentuk tabel dan teks.

\section{Asfiksia pada bayi baru lahir}

Tabel 1 Distribusi Frekuensi Responden berdasarkan kejadian Asfiksia

\begin{tabular}{clcc}
\hline No & Asfiksia & n & Persentase \\
\hline 1 & Ya & 92 & 32,1 \\
2 & Tidak & 195 & 67,9 \\
\hline Jumlah & 287 & 100 \\
\hline
\end{tabular}

Dari tabel diatas dapat diketahui bahwa bayi yang mengalami asfiksia sebanyak 92 responden $(32,1 \%)$ dan bayi yang tidak mengalami asfiksia sebanyak 195 responden $(67,9 \%)$.

\section{Ketuban Pecah Sebelum Waktunya} (KPSW)

Tabel 2 Distribusi Frekuensi Responden berdasarkan Ketuban Pecah Sebelum Waktunya (KPSW)

\begin{tabular}{clcc}
\hline No & KPSW & n & Persentase \\
\hline 1 & KPSW & 33 & 11,5 \\
2 & Tidak KPSW & 254 & 88,5 \\
\hline & Jumlah & 287 & 100 \\
\hline
\end{tabular}

Dari tabel diatas diketahui bahwa ibu yang mengalami KPSW sebanyak 33 responden $(11,5 \%)$ dan ibu yang tidak mengalami KPSW sebanyak 254 responden $(88,5 \%)$.
3. Persalinan Secsio Sesarea

Tabel 3 Distribusi Frekuensi Responden berdasarkan Persalinan Secsio Sesarea

\begin{tabular}{clcc}
\hline No & $\begin{array}{c}\text { Persalinan Secsio } \\
\text { Sesarea }\end{array}$ & n & Persentase \\
\hline 1. & Persalinan Secsio & 163 & 58,6 \\
& sesarea & 124 & 43,2 \\
2. & $\begin{array}{l}\text { Persalinan tidak } \\
\text { Secsio sesarea }\end{array}$ & \\
\hline \multicolumn{2}{l}{ Jumlah } & \multicolumn{1}{c}{287} & 100 \\
\hline & Dari tabel diatas diketahui bahwa ibu
\end{tabular}

yang mengalami persalinan secsio sesarea sebanyak 163 responden $(58,6 \%)$ dan ibu yang tidak mengalami persalinan secsio sesarea sebanyak 124 responden $(43,2 \%)$.

4. Hubungan KPSW dengan Kejadian Asfiksia pada Bayi Baru Lahir

Tabel 4 Hubungan KPSW dengan Kejadian Asfiksia

\begin{tabular}{|c|c|c|c|c|c|c|c|c|}
\hline \multirow{3}{*}{$\begin{array}{l}\mathbf{N} \\
\mathbf{0}\end{array}$} & \multirow{3}{*}{ KPWS } & \multicolumn{4}{|c|}{ Kejadian Asfiksia } & \multirow{2}{*}{\multicolumn{2}{|c|}{ Jumlah }} & \multirow{3}{*}{$\begin{array}{c}P \\
\text { value }\end{array}$} \\
\hline & & \multicolumn{2}{|c|}{ Ya } & \multicolumn{2}{|c|}{ Tidak } & & & \\
\hline & & $\mathbf{n}$ & $\%$ & $\mathbf{n}$ & $\%$ & $\mathbf{N}$ & $\%$ & \\
\hline 1 & $\mathrm{Ya}$ & 18 & 54,5 & 15 & 45,5 & 33 & 100 & 0,006 \\
\hline 2 & Tidak & 74 & 29,1 & 180 & 70,9 & 254 & 100 & \\
\hline & Jumlah & 92 & & 195 & & 287 & & \\
\hline
\end{tabular}

Tabel diatas menunjukkan bahwa dari 33 responden yang mengalami Ketuban Pecah Sebelum Waktunya (KPSW) terdapat 18 responden $(54,5 \%)$ yang mengalami asfiksia dan yang tidak mengalami asfiksia yaitu 15 responden $(45,5 \%)$, sedangkan dari 254 responden yang ketuban tidak pecah dini terdapat 74 responden $(29,1 \%)$ yang mengalami asfiksia dan yang tidak mengalami asfiksia yaitu 180 responden (70,9\%).

Hasil pengujian statistik menunjukkan bahwa ada hubungan yang bermakna antara Ketuban Pecah Sebelum Waktunya (KPSW) dengan kejadian asfiksia, dimana $\mathrm{p}$ value $=$ 0,006 lebih kecil dari $\alpha=0,05$. Sehingga hipotesis yang menyatakan ada hubungan antara Ketuban Pecah Sebelum Waktunya (KPSW) dengan kejadian asfiksia di Rumah Sakit PT Graha Pusri Medika Palembang.

5. Hubungan Persalinan Secsio Sesarea dengan Kejadian Asfiksia pada Bayi Baru Lahir 
Tabel 5 Hubungan Persalinan Secsio Sesarea dengan Kejadian Asfiksia

\begin{tabular}{|c|c|c|c|c|c|c|c|c|}
\hline \multirow{3}{*}{$\begin{array}{l}\mathbf{N} \\
\mathbf{0}\end{array}$} & \multirow{3}{*}{$\begin{array}{c}\text { Persalinan } \\
\text { SC }\end{array}$} & \multicolumn{4}{|c|}{ Kejadian Asfiksia } & \multirow{2}{*}{\multicolumn{2}{|c|}{ Jumlah }} & \multirow{3}{*}{$\begin{array}{c}P \\
\text { value }\end{array}$} \\
\hline & & \multicolumn{2}{|c|}{ Ya } & \multicolumn{2}{|c|}{ Tidak } & & & \\
\hline & & $\mathbf{n}$ & $\%$ & $\mathbf{n}$ & $\%$ & $\mathbf{N}$ & $\%$ & \\
\hline 1 & $\mathrm{Ya}$ & 63 & 38,7 & 100 & 61,3 & 163 & 100 & 0,009 \\
\hline 2 & Tidak & 29 & 23,4 & 95 & 76,6 & 124 & 100 & \\
\hline & Jumlah & 92 & & 195 & & 287 & & \\
\hline
\end{tabular}

Tabel diatas menunjukkan bahwa dari 163 responden yang mengalami persalinan secsio sesarea terdapat 63 responden $(38,7 \%)$ yang mengalami asfiksia dan yang tidak mengalami asfiksia yaitu 100 responden $(61,3 \%)$, sedangkan dari 124 responden yang tidak mengalami persalinan secsio sesarea terdapat 29 responden $(23,4 \%)$ yang mengalami asfiksia dan yang tidak mengalami asfiksia yaitu $95(76,6 \%)$.

Hasil pengujian statistik menunjukkan bahwa ada hubungan yang bermakna antara persalinan secsio sesarea dengan kejadian asfiksia, dimana $p$ value $=0,009$ lebih kecil dari $\alpha$ $=0,05$. Sehingga hipotesis yang menyatakan ada hubungan antara persalinan secsio sesarea dengan kejadian asfiksia di Rumah Sakit PT Graha Pusri Medika Palembang.

\section{PEMBAHASAN}

\section{Asfiksia pada bayi baru lahir}

Pada penelitian ini kejadian asfikisa dibagi menjadi 2 kategori yaitu asfiksia (Bila bayi tidak dapat segera bernafas secara spontan setelah bayi lahir APGAR $<7$ dan diagnosa dokter asfiksia) dan tidak asfiksia (Bila bayi dapat segera bernafas secara spontan setelah bayi lahir APGAR $\geq 7-10$ dan diagnosa dokter tidak asfiksia). Data dikumpulkan dengan menggunakan check list yang telah disiapkan.

Hasil penelitian ini menunjukkan bahwa responden yang mengalami asfiksia sebanyak 92 responden $(32,1 \%)$ dan responden yang tidak mengalami asfiksia sebanyak 195 responden $(67,9 \%)$.

Menurut hasil penelitian ini menunjukkan kejadian asfiksia masih cukup tinggi yaitu dari 287 kelahiran terdapat 92 kejadian asfiksia hal ini disebabkan karena kurangnya pengetahuan ibu tentang asfiksia.

\section{Hubungan Ketuban Pecah Sebelum Waktunya (KPSW) dengan kejadian Asfiksia}

Penelitian ini dilakukan pada 287 responden dimana pendidikan responden dikelompokkan menjadi 2 (dua) kategori yaitu
Ketuban Pecah Sebelum Waktunya (KPSW) (Bila pecahnya selaput ketuban sebelum persalinan tanpa disertai tanda inpartu) dan ketuban tidak pecah dini (Bila selaput ketuban tidak pecah sebelum persalinan dan tanpa disertai tanda inpartu). Sedangkan kejadian asfiksia dibagi menjadi 2 kategori yaitu asfiksia (Bila bayi tidak dapat segera bernafas secara spontan setelah bayi lahir APGAR $<7$ dan diagnosa dokter asfiksia) dan tidak asfiksia (Bila bayi dapat segera bernafas secara spontan setelah bayi lahir APGAR $\geq 7$ dan diagnosa dokter tidak asfiksia). Data dikumpulkan dengan cara melihat rekam medik dengan menggunakan check list yang sudah disusun peneliti.

Hasil analisa univariat, menunjukkan bahwa responden yang mengalami Ketuban Pecah Sebelum Waktunya (KPSW) sebanyak 33 responden $(11,5 \%)$ dan responden yang tidak mengalami Ketuban Pecah Sebelum Waktunya (KPSW) sebanyak 254 responden $(88,5 \%)$.

Hasil analisis bivariat, menunjukkan bahwa proporsi 33 responden yang mengalami Ketuban Pecah Sebelum Waktunya (KPSW) yang mengalami asfiksia sebanyak 18 responden $(54,5 \%)$ yang tidak mengalami asfiksia sebanyak 15 responden $(45,5 \%)$. Sedangkan dari 254 responden dengan tidak mengalami Ketuban Pecah Sebelum Waktunya (KPSW) mengalami asfiksia sebanyak 74 responden $(29,1 \%)$ dan 180 responden $(70,9 \%)$ yang tidak mengalami asfiksia

Berdasarkan hasil uji Chi-Square didapatkan $p$ value $=(0,006) \quad(\alpha=(0,05))$ yang berarti ada hubungan yang bermakna antara Ketuban Pecah Sebelum Waktunya (KPSW) dengan kejadian asfiksia. Sehingga hipotesis penelitian (Ha) yang menyatakan ada hubungan yang bermakna antara Ketuban Pecah Sebelum Waktunya (KPSW) dengan kejadian asfiksia pada bayi baru lahir di Rumah Sakit PT Graha Pusri Medika Palembang terbukti secara statistik.

Menurut Dwi Keshi (2010) dalam Penelitian ini dilakukan di RS Bhakti Yudha Depok. Populasi pada penelitian ini adalah semua ibu dengan Ketuban Pecah Sebelum Waktunya (KPSW) serta bayi baru lahir dari ibu dengan Ketuban Pecah Sebelum Waktunya (KPSW) di RS Bhakti Yudha Depok periode 2008-2009. Dengan Besar sampel yaitu sebesar 63 pasien dan cara 
pengambilan sampel dengan teknik simple random sampling. Analisis data menggunakan uji Chi-square. Hasil analisis bivariat menunjukkan $\mathrm{p}=0,021$. Karena $\mathrm{p}<0,05$ maka Ho ditolak dan Ha diterima. Sehingga terdapat hubungan antara Ketuban Pecah Sebelum Waktunya (KPSW) dengan kejadian asfiksia neonatorum.

Menurut Murtanti tahun 2010, hasil penelitian menunjukkan sebagian besar ibu bersalin dengan Ketuban Pecah Sebelum Waktunya (KPSW) di RSUD Dr. R. Koesma Tuban Tahun 2009 melahirkan bayi asfiksia $65(81,25 \%)$. Dari hasi uji statistik dengan mengunakan uji Chi Square didapatkan nilai frekuensi $p$ value $(0,006)$ lebih kecil dari pada $\alpha(0,05)$, maka Ha diterima artinya ada hubungan antara Ketuban Pecah Sebelum Waktunya (KPSW) dengan kejadian asfiksia pada bayi baru lahir.

Dari hasil pengumpulan data dilakukan melalui studi dokumentasi yang kemudian dianalisis dengan menggunakan uji chi kuadrat dengan taraf signifikansi $5 \%$ dan df 2 . Berdasarkan penghitungan yang dilakukan dengan menggunakan chi kuadrat, didapatkan x2 hitung 18,643 sementara dengan $\mathrm{db}=2$ didapatkan $\mathrm{x} 2$ tabel 5,991. Ternyata $\mathrm{x} 2$ hitung lebih besar daripada $\mathrm{x} 2$ tabel, yang berarti bahwa ada hubungan terjadinya Ketuban Pecah Sebelum Waktunya (KPSW) (KPSW) pada saat persalinan dengan terjadinya asfiksia pada Bayi Baru Lahir (BBL) di RSU PKU bulan September-Mei (Yuliana, 2010).

Dari penelitian diatas dapat dibuktikan bahwa kejadian KPSW mempengaruhi kejadian asfiksia pada bayi baru lahir karena terjadinya kompresi tali pusat, deformitas janin, sehingga meningkatnya insiden seksio sesarea, atau gagalnya persalinan normal. Dengan pecah dini terjadi oligohidramnion yang menekan tali pusat hingga terjadi asfiksia atau hipoksia.

\section{Hubungan Persalinan Secsio Sesarea dengan kejadian Asfiksia}

Penelitian ini dilakukan pada 287 responden dimana persalinan secsio sesarea dikelompokkan menjadi 2 (dua) kategori yaitu persalinan secsio sesarea (Apabila ibu melahirkan dengan secsio sesarea) dan tidak secsio sesarea (Apabila ibu melahirkan tidak dengan secsio sesarea). Sedangkan kejadian asfiksia dibagi menjadi 2 kategori yaitu asfiksia (Bila bayi tidak dapat segera bernafas secara spontan setelah bayi lahir APGAR $<7$ dan diagnosa dokter asfiksia) dan tidak asfiksia (Bila bayi dapat segera bernafas secara spontan setelah bayi lahir APGAR $\geq$ 7-10 dan diagnosa dokter tidak asfiksia). Data dikumpulkan dengan melihat rekam medik dengan pengisian check list yang sudah disusun peneliti.

Hasil analisa univariat, menunjukkan bahwa responden yang mengalami persalinan secsio sesarea sebanyak 163 responden $(56,8 \%)$ dan responden yang tidak mengalami persalinan secsio sesarea sebanyak 124 responden $(43,2 \%)$.

Hasil analisis bivariat, menunjukkan bahwa proporsi 163 responden yang mengalami persalinan secsio sesarea yang mengalami asfiksia sebanyak 63 responden $(38,7 \%)$ dan yang mengalami asfiksia sebanyak 100 responden $(61,3)$ lebih besar dibandingkan proporsi responden yang tidak mengalami persalinan secsio sesarea yang mengalami asfiksia sebanyak 29 responden $(23,4 \%)$ dan yang tidak mengalami asfiksia sebanyak 95 responden (76,6\%).

Berdasarkan hasil uji Chi-Square didapatkan $p$ value $=(0,009) \quad(\alpha=(0,05))$ yang berarti ada hubungan yang bermakna antara persalinan secsio sesarea dengan kejadian asfiksia. Sehingga hipotesis penelitian (Ha) yang menyatakan ada hubungan yang bermakna antara persalinan secsio sesarea dengan kejadian asfiksia pada bayi baru lahir di Rumah Sakit PT Graha Pusri Medika Palembang terbukti secara statistik.

Menurut Hariati 2011, berdasarkan hasil penelitiannya di RSUD Pekanbaru didapatkan 266 responden dan diperoleh bayi yang mengalami asfiksia sebanyak 52,6\%, bayi yang dilahirkan melalui seksio seasarea sebanyak $65,0 \%$, bayi dengan kelahiran prematur sebanyak 27,4\%. Ada hubungan antara seksio sesarea dengan asfiksia pada bayi baru lahir dengan nilai $p$ value $=0,015$.

Menurut Dwi Cahya Febrimulya (2010) Penelitian ini menggunakan data sekunder rekam medik yang diambil dari RSUD Dr. Soetomo Surabaya pada periode AgustusSeptember 2009 dianalisis secara analitik dengan rancangan penelitian cross sectional. Hasil dan kesimpulan dari penelitian ini menunjukkan bahwa bayi baru lahir dengan persalinan seksio sesarea memiliki risiko asfiksia lebih tinggi dari pada persalinan 
spontan. Bayi baru lahir dengan persalinan seksio sesarea yang mengalami asfiksia sebanyak $8,03 \%$ sedangkan bayi baru lahir dengan persalinan spontan yang mengalami asfiksia sebanyak $2,47 \%$ dengan nilai $p$ value $(0,004)$ lebih kecil dari pada $\alpha(0,05)$. Jadi, dari penelitian ini dapat disimpulkan bahwa ada hubungan antara persalinan seksio sesarea dengan kejadian asfiksia pada bayi baru lahir.

Menurut Istikomah (2011) berdasarkan hasil penelitiannya di RS. Bakti Rahayu Surabaya populasi sebanyak 190 ibu bersalin dan bayi serta 129 ibu bersalin dan bayi sebagi sampel dengan tehnik pengambilan sampel secara simple random sampling dan data dianalisis dengan uji Chi-Square dengan $\alpha=0,05$. Hasil penelitian didapatkan sebagian besar jenis persalinan di RS. Bakti Rahayu yaitu sebanyak $(74,42 \%)$ persalinan secara secsio sesarea dan sebagian besar $(51,94 \%)$ bayi baru lahir dalam keadaan asfiksia. Dari uji chi-square didapatkan $\chi^{2}$ hitung $=9,84$ dan pada $\chi^{2}$ tabel $=5,99$. Karena $\chi^{2}$ hitung $>\chi^{2}$ tabel maka $\mathrm{H}_{0}$ ditolak, berarti ada hubungan antara jenis persalinan dengan kejadian asfiksia pada bayi baru lahir.

Dari hasil penelitian di atas dapat dibuktikan bahwa persalinan dengan sectio sesarea dapat mempengaruhi kejadian asfiksia pada bayi baru lahir, hal ini disebabkan karena persalinan secsio sesarea akan memicu pengeluaran hormon stres pada ibu yang diperkirakan menjadi kunci pematangan paruparu bayi yang terisi air sehingga bayi lahir mengalami asfiksia.

\section{KESIMPULAN}

Hasil penelitian menunjukkan bahwa ada hubungan yang bermakna antara KPSW dengan kejadian asfiksia dengan $P$ value $(0,006)$, ada hubungan yang bermakna antara persalinan SC dengan kejadian asfiksia dengan $P$ value (0.009).

\section{DAFTAR PUSTAKA}

Annisa, Silvia Aulia. 2011. Faktor-faktor Risiko Persalinan Sectio Sesaria. (http://www.fkm.undip.ac.ad.

Arief. 2009, Neonatus dan Asuhan Keperawatan Anak, Nuha Medika: Yogyakarta.

Depkes RI, 2008. Profil Kesehatan Indonesia 2010. (http://www.depkes.com.

Depkes RI, 2009. Profil Kesehatan Indonesia. (http://www.depkes.com.
Dewi, Vivian Nani Lia. 2011. Asuhan Neonatus Bayi Anak dan Balita. Salemba Medika: Jakarta.

Dinkes, 2006. Profil Dinas Kesehatan. (http://www.dinkes.com.

Fatimah, Siti. 2009, Hubungan antara ketuban pecah dini dengan kejadian asfiksia, (http://www.scribd.com/doc/114865143/A sfiksia-Neonatorum-di-ruang-NeonatusRSUD-Sidoarjo.

Febrimulya, Dwi Cahya. 2009, Hubungan antara Persalinan secsio sesarea dengan kejadian asfiksia, (http://alumni.unair.ac.id/kumpulanfile/445 38815718_abs.pdf.

Istikomah. 2011, Hubungan antara Persalinan secsio sesarea dengan kejadian asfiksia, (http://share.stikesyarsis.ac.id/elib/main/do k/00400/hubungan-antara-jenis-persalinandengan-kejadian-asfiksia-pada-bayi-barulahir-di-rumah-sakit-bakti-rahayusurabaya.

JNPK-KR. 2008. Asuhan Persalinan Normal dan Penatalaksaan Bayi Baru Lahir dengan Asfiksia. Jaringan Nasional Pelatihan Klinik : Jakarta.

Keshi, Dwi. Hubungan antara ketuban pecah dini dengan kejadian asfiksia, (http://www.library.upnvj.ac.id/pdf/4s1ked okteran/207311068/Abstrak.pdf.

Kristiyanasari, Weni. 2009, Neonatus dan Asuhan Keperewatan Anak, Nuha Medika: Yogyakarta.

Marmi. 2012. Asuhan Kebidanan Pada Persalinan, Pustaka Pelajar: Yogyakarta.

Murtanti, 2010. Ketuban pecah sebelum waktunya, (http://chellious wordpress.com.

Ningsih, Yuliati. 2012, Hubungan antara berat bayi lahir rendah dengan kejadian asfiksia,

(http://www.kampusmajapahit.ac.id/wpcontent/uploads/2012/05/poltekkes.pdf.

Notoatmodjo, Soekidjo. 2010. Metodologi Penelitian Kesehatan. Rineka Cipta : Jakarta.

Pantiawati, Ika. 2010. Bayi dengan BBLR. Nuha Medika: Yogyakarta.

Prawirohardjo, S. 2005. Ilmu Kebidanan. Jakarta: Yayasan Bina Pustaka Sarwono Prawirohardjo.

Prawirohardjo, S. 2009. Ilmu Kebidanan. Jakarta: Yayasan Bina Pustaka Sarwono Prawirohardjo.

Profil Rumah Sakit Bhayangkara Palembang Tahun 2013. 
Proverawati, Atikah. 2010. Berat Bayi Lahir Rendah. Nuha Medika: Yogyakarta.

Retno, Dwi. 2011, proposal penelitian BBLR dengan kejadian asfiksia, (http://www.ilmukita.co.id.

Rukiyah, Ai Yeyeh. 2010. Asuhan Neonatus Bayi danAnak Balita. Trans Info Media : Jakarta.

Sitepu, Neneng Yelis. 2011, Hubungan antara jenis pesalinan dengan kejadian asfiskia neonatorum,

(http://alumni.unair.ac.id/kumpulanfile/591 23815491 abs.pdf.

Sudarti. 2013. Asuhan Kebidanan Neonatus Risiko Tinggi dan Kegawatan, Nuha Medika: Yogyakarta.

Syaifudil, Abdul Bari. 2007. Pengertian persalinan secara Seksio Sesarea. (http://pravitamegaresky.blogspot.com/201 2/12/kti-gambaran-persalinan-seksiosesarea.html.

Winknjosartro, Gulardi. 2008, Asuhan Persalinan Normal, Jaringan Nasional Pelatihan Klinik : Jakarta.

Yuliana, Septi. 2010. Hubungan antara KPSW dengan kejadian asfiksia. (http://yulianasept.blogspot.com. 
